\title{
Challenging a place myth: New Zealand's clean green image meets the biotechnology revolution
}

\author{
Fiona Coyle and John Fairweather
}

AERU, PO Box 84, Lincoln University, Canterbury, New Zealand

Email: leadora2000@yahoo.com

\begin{abstract}
The 'clean green image' of New Zealand is a well-known example of what has been called a 'place myth'. But more recently, emerging alongside this place myth is an image that the government is trying to co-create of New Zealand as an innovator in biotechnology. In nationwide focus groups, whilst a matter of pride, participants typically saw this clean green myth as a temporally distant utopia. However, when considered alongside the futures proposed by biotechnology, clean green New Zealand was mobilized into the present moment to defend a general reluctance to take up these practices. Alternately, some participants saw the possibility for co-evolution of the place myths, with biotechnology enabling the re-construction of a 'pictureperfect', clean green country.
\end{abstract}

Keywords: New Zealand, place myth, focus groups, clean green, biotechnology

\section{Introduction}

Imagine that you live in Asia, or Britain, or perhaps the US. You have driven home through the smog to your cramped apartment, and as you eat your dinner you see on TV images of snow-capped mountains reflected in crystal-clear unpolluted lakes. Cows graze in lush green pastures, native birds sing in the forests, waves thunder onto deserted beaches, and happy healthy people are having fun. It is New Zealand, and it looks like paradise. (Ministry for the Environment 2001)

New Zealanders and visitors to New Zealand often remark that one of the main attributes of the country is its clean green image. Although constructed around earlier mythologies, this place descriptor is a fairly recent one, originating in the mid $1980 \mathrm{~s}$, around the time the Greenpeace vessel, the Rainbow Warrior, sank off the coast of South Island (Sanderson et al. 2003, 3). Its emergence also coincided with the passing of a government act that designated New Zealand as a nuclear-free zone (Sanderson et al. 2003, 3). Coined in the milieu of this nuclear-free status, the image was quickly utilized as a marketing tool that extended to broader environmental issues.

As Dew suggests:

The symbol of clean and green New Zealand provides a very strong cultural resonance which strengthens chains of cultural meaning and provides a strong impetus for action. $(1999,53)$ 
When 'this symbol is grounded in the nation's self-image and its economic dependency' $(1999,53)$, it was not surprising that, during a series of nationwide focus group discussions about biotechnology, 'clean green New Zealand' frequently arose as an area of contentious debate. But what does this image mean to the public? What is its connection to biotechnology?

We argue in this paper that whilst an image of clean green New Zealand is strongly embedded in the cultural imagination, it is generally perceived as a temporally distant Utopia. It is either a state of becoming, or was frozen in the safe space of history. However, when this Utopia is threatened by particular biotechnologies such as genetic engineering, New Zealanders' sensitivity to clean and green is heightened in such a way that New Zealand literally 'becomes' just that. The signifiers shift to the present moment, held there through comparisons to other nations and continents. To interpret this, we utilize the early work of Rob Shields (1991) on social spatialization, and his dual concepts of 'Place Myth' and 'Place Image'. Similar concepts have also been developed and applied to New Zealand by Bell (1996 2002) in her interpretation of identity myths. We build on these approaches and extend them by suggesting that the place myth of clean green New Zealand is challenged by the new government policy of recreating the country as a centre of biotechnology innovation. However, as focus groups with the New Zealand public suggest, the compatibility of the two can be problematic and a simple repositioning of the economy may not be consistent with dominant notions of the clean green place myth.

In this paper, we first review the concepts of place myth and place image before outlining the focus group method that we used to acquire information from members of the New Zealand public about their attitudes towards the clean green image and biotechnology. We then examine the meaning of this national place myth for members of the focus groups, and explore its temporal suspension in past and future spaces. Our data show that when the place myth of New Zealand as a biotechnology core enters the picture, the clean green image is mobilized and drawn into the present tense. We explore how and why this occurs and note the ambivalence of responses to the co-evolution of the two place myths.

\section{A clean green place myth}

Shields (1991) proposed that, over a period of time, complex social interactions within and between locations lead to the emergence of particular connotations and symbolic meanings that form a 'place image'. He defines these as: 'The various discrete meanings associated with real places or regions regardless of their character in reality' (1991, 60). Place images are always partial, often exaggerated or understated, and may or may not provide an accurate representation of everyday life in these locales. They are often simplified versions of reality; a result of stereotyping or prejudice towards locales or their inhabitants. However, the core images that form this stereotyping are usually persistent and have a degree of stability that according to Shields circulates in a popular 'discursive economy'. Peripheral to place images, but feeding into them, are individual experiences of place that move beyond mere picture-postcard representations. At a broader scale level, Shields calls a conglomeration of interrelated place images a 'place myth'. Whilst relatively stable entities, they evolve over time; as core images of place can radically alter, others lose their symbolic power and devolve into 'dead metaphors', and are replaced by new inventions that become more acceptable representations (Shields 1991, 61). ${ }^{1}$ Regions can be dominated by these place myths, for instance, 'True North, Strong and Free' of Canada, or the 'Shrine of Nature', Niagara Falls (Shields 1991, 257-8). 
Shield's concepts allow us to better understand the utilization of imagery in New Zealand, and one important place myth here is known commonly as the 'clean green' image. It has been a dominant part of national consciousness for at least two decades, but is a simplified view of reality for many people. The place myth of clean green New Zealand has a complex genealogy, and is bolstered by a number of place images of the country as an Arcadia, ' $100 \%$ PURE',' 'beautiful New Zealand', the pastoral idyll, a tourist paradise, nuclear free and a desirable place to live. According to Claudia Bell (1996), this clean green myth was constituted through a complex history of New Zealanders' relationship to nature and the environment. For early settlers, New Zealand was constructed as an Arcadia, with artists recreating the romantic, sublime landscape of Europe in this Antipodean paradise. These representations marketed the country as an aesthetically consumable landscape, and hence appealing to tourists and immigrants. Yet even at this early stage, "beautiful New Zealand" meant "exploitable New Zealand"' as the consumption of this sublime paradise became a selling point; 'a saleable bit of Arcadia' (Bell 1996, 31). Such exploitation continues today with tourism, one of the largest export industries, making the most of clean green New Zealand.

Under recent discussion has been the issue of the sustainability of this clean and green place myth. In the early 1990s, a study suggested that clean and green has become a phrase that was known to most New Zealanders, but that just under half of the population surveyed thought that the concept was a myth (Gendall et al. 1993). In a recent report on sustainable development by the Parliamentary Commissioner for the Environment, researchers stated that New Zealand would lose its clean green brand image if it did not veer towards more sustainable practices. In particular, the report pointed out problems '... related to urban growth, land and water use and biosecurity threats' (Fleming 2002, 2) and suggested that New Zealand faced "significant economic risks" if it [let] the gap between its international image and reality grow' (Fleming 2002, 2).

While some farming and conservation practices may be questioned for their sustainability, according to Bell $(1996,53)$, the clean green image still rings true, in part because it is repeatedly emphasized through media, advertising and political statements, in part because the pollutants are often invisible to the eye, their impacts only occurring later through untraceable ill health (see Beck 1992; Dew 1999, 54). With regards to the former, it may well be that tourism advertising influences New Zealanders as much as it influences international tourists. Concerning the latter, Bell thinks that New Zealanders sometimes ignore these interruptions in favour of the emotional salve of 'clean green' countryside that is strongly embedded into the national consciousness (Bell 1996, 53). What she is suggesting is that New Zealanders may be reluctant to admit inaccuracies in the nation's treasured images that are in effect a challenge to that image. However, there are times when interruptions or challenges are not ignored and in these instances appeals are made to clean green imagery. For example, rapid expansion of dairy farming using irrigation on formerly dryland regions has led to concerns about groundwater pollution and the effects of stock effluent on stream quality and fishing (Prestwood 2001; Morgan 2002). Also the use of $1080^{3}$ for poisoning pests on forested conservation land and farmland has led to concerns about the impact of widespread applications on the health of the environment (Murdoch 2001; Napp 2002). Protests against such developments would seem to be motivated by a desire to retain or improve the clean green image. These changes challenge the dominant image and they are appraised against notions of a clean and green New Zealand, even if adherents to the place myth acknowledge that it may not be perfect. Our research on public perceptions of biotechnology shows that biotechnology appears to be one of these 
interruptions. Before describing our results in detail we outline the focus group method used to develop our understanding of current use of the clean green place myth.

\section{Methods}

We drew upon the focus group method for data collection because it has a number of significant advantages over other techniques such as surveys and interviews. ${ }^{4}$ In our case, focus groups provided an opportunity to explore the links between biotechnology and the emergent concept of clean green New Zealand. Our own research was based on 11 nationwide focus groups with 117 participants. These groups were primarily in the main urban centres of New Zealand. Ten to 12 participants approximated a representative sample according to age, gender, ethnicity and socio-economic background. In addition to this, an 'Asian' focus group and a Pacific Islander focus group were also convened in Auckland to reflect its diverse population structure. Participants were presented with a series of exemplars of recent developments in environmental, agricultural and medical biotechnologies that pertained specifically to New Zealand. These examples had either been recently introduced (a lozenge for sore throats made with bacteria cultured from human saliva); existed under controlled experimental conditions (potatoes with a synthetic toad gene inserted into them, to combat soft rot; a GM bacterium to clean up DDT contamination in the soil; and a bolus containing bacteria that would reduce methane production in sheep's digestive tract to help cut down on greenhouse gas contributions) or were currently in the early stages of experimentation (embryonic stem cell research for Alzheimer's disease). Participants were given ranking sheets and asked to rank the biotechnologies on a scale of $1-5,1$ being most acceptable and 5 being least acceptable. They were also asked to write a few notes to justify their reasoning, in preparation for discussion. The groups were then asked to talk about their decisionmaking process, a lengthy procedure that took up half of the allotted time. Nevertheless, this structured approach allowed all participants to have a voice, in contrast to a more open call for discussion. The sheets were then collected and, at a later point, examined to provide extra data on decisionmaking.

The second half of the focus group was more informal, and varied according to the time remaining, the social mix of the group and previous experiences. It focused primarily on two dominant themes that emerged during pilot studies: nature and safety/risk. ${ }^{5}$ Participants were introduced to further exemplars that included: the xenotransplantation of porcine pig cells into diabetics; a herd of cloned, transgenic sheep in the North Island, whose milk would produce a protein to help patients with cystic fibrosis; DNA testing of agricultural products to verify their New Zealand origins; the transfer of healthy bacteria from yoghurt into cheese. Group members were also introduced to a series of summary statements made by members of some pilot focus groups, and asked to make comments about what people meant by these statements and to what extent they were in agreement.

Once transcribed, the written data were re-read and loose themes manually deduced from the text. Furthering this, they were then coded using the qualitative data analysis package, NVivo. This process was guided via a word-searching tool in the software, in addition to some of the themes that emerged through manual coding. Emergent themes were varied and included New Zealand's clean green image, particularly in relationship to the fluid concept of 'nature'. The theme first appeared during an ice breaker question about how participants would like to see the country in 20 years time, and was later mobilized to defend positions 
on biotechnologies such as GE, DNA testing and proposed measures to cut down greenhouse gas production.

\section{In suspension: a clean green New Zealand?}

Before coming to New Zealand, my idea of New Zealand is that New Zealand is a clean and green country, and that's why I move here, like you. And I think in 20 years time New Zealand should stay the way it is right now ... if you don't maintain the status like what it is in New Zealand right now then we don't have a good product. You have an icon like clean and green and you can still maintain this icon here if you go into this field then you've got to change the whole icon of New Zealand. (Asian male, Auckland)

During the focus group with members of the Asian population, one man referred to the clean green image as an 'icon'- symbolic of New Zealand culture and national identity. As an immigrant, he was critically aware of its emblematic nature. However, it was a powerful enough place myth to propel him to leave Asia, and be drawn to New Zealand, as he later attested. This focus on iconography was a contrast to the more emotive feelings that arose for many European New Zealanders (Pakeha) when they thought about the future of their nation. These emerged as positive comments, such as, "Clean green image is the place I prefer to live in'; 'We sell our meat because we have this nice, clean and green environment' or 'I think we've got to make quite sure we always keep a clean green environment in New Zealand'.

Data from the focus groups parallel recent writings on clean green New Zealand, and imply that the place myth merges the purity of a nature rooted in tradition, with the benevolent good of a nature that is wise and healing (see Coyle et al. 2003). As Bell suggests, in New Zealand, "the public celebration of nature implies a "natural order" in which nature is good, in harmony with the population' $(1996,54)$. The naturalistic place images of ' $100 \%$ PURE' New Zealand, 'Brand New Zealand' and 'Beautiful New Zealand' evoked by glossy tourist brochures filter into the core myth of clean green New Zealand, with a national identity based on the centrality of nature. Indeed, Bell suggests:

in New Zealand, we can see that nature and landscape have become a powerful identity 'myth'. 'Green' is a splendid example of this; myth transforms nature into history and political expediency. We can then sell it to tourists as national identity; and half-believe it ourselves. $(1996,48)$

For example:

It's just the quality of air, water ... tourism; you see pictures of crystal clear water. I've travelled to a few cities where the air is diabolical you can see the smog hanging around. (Female, Auckland)

I don't want us to lose this clean green image that on a whole we do have, that people always seem to comment on ... all wonderful nature walks for heritage, having a beach 20 minutes away. I want that to be there for future generations. I want to always be happy living in New Zealand. I don't see another country I'd rather live in. (Female, Dunedin) 
In theory, as these comments imply, the clean green place myth is associated with an abundance of accessible natural environment - a cultural imaginary that is pure and unspoilt. Moreover, this clean green image has a materiality to it, for New Zealand was perceived by participants as a 'healthy' place to live and a 'good place to bring up kids'.

The two terms, New Zealand and clean/green, were to some extent synonymous with one another, suggesting the embeddedness of the concept in national consciousness. However, as one participant suggested, not everybody felt the same positive associations with the term or considered it part of their national identity. Rather, 'It's something that we value, but there are an enormous number of families that don't even appear to feel it's a concept worth valuing'. Thus, whilst the clean green place myth was recognized and embraced by New Zealanders, there was a strong realization that this icon was merely that. Namely, New Zealand was not as clean and green as the population liked to consider it to be: 'Keep its green image, but I don't think it's as green as people think it is. More organics, agriculture to go organic on a much bigger scale' or 'The country has a tendency to bask now and to say that it's clean and green and not actually looking at the reality of what it's really like'.

Focus group participants were starkly aware that New Zealand faced similar environmental threats to other regions. For instance, Christchurch faces a problem over highly visible wintertime smog, Auckland rapidly encroaches on neighbouring rural landscapes and also has a visible pollution problem: 'I was driving along the motorway the other day and it was trying to rain and you could see the grey on the vehicles in front of you. Quite frightening, what's actually happening' (Male, Auckland). In such narratives, the 'green' usually associated with New Zealand was replaced by 'grey', and 'clean' by evocative images of dirtiness.

The clean green icon often emerged when participants expressed a desire to stop this destructive progress and freeze the place image in a state of nature that could be described as traditional.

I'd like it to stay the same. Well, the image that it has now, if not improve a little bit. Like, if they were to possibly keep the same it might not be the same, the way that they're continuing ... I don't want concrete. Keep the green, nice. (Female, Dunedin)

Here, we see the emergence of a more realist counter place image, locally mediated, and one that we argue undermines the clean green myth politicized by government and private marketing, and temporally (as well as spatially) partitions it into an existence located in the past and future. Namely, with the increasing recognition of environmental degradation, the icon of clean green New Zealand was perceived as temporally polarized, for this national place myth exists as a Utopian imaginary unstably located in either historical spaces, spaces of the future or the virtual, transcendent spaces of glossy advertising pamphlets.

For focus group participants, the marketing myth of clean green New Zealand did not generally appear to be an accurate iconographic representation of the present. Instead, for many it existed in the untainted space of 'traditional nature', 6 temporally distant from the present: 'I think we forget about looking back into how things used to be, natural' (Female, Dunedin) or 'I think most things are not part of nature nowadays. Things have changed. Nature is the original' (Pacific Island male, Auckland). Traditional nature existed prior to the birth of participants, or through childhood memories, a nature steeped in nostalgia. In particular, the following statement was an effective illustration of these arguments: 
To a certain extent I think the clean green image is what we may remember from when we were younger. What we'd like New Zealand to be. It's a wish list for most. We have a way to go to become truly clean. (Female, Auckland)

As this comment insinuates, the clean green place myth was an ideal imaginary projected into the future from this recent/distant past. It was both an ideal that once was, and one that we should be aiming for: 'I would like to see New Zealand go back to the green that it used to be and that everyone else has talked about' (Male, Auckland) or 'I would like to see a clean, green New Zealand, which to me is essential for up and coming generations' (Male, Waimate):

I think you've got to fight though. That Helen Clark [the Prime Minister]- I see her as being a fighter for every bit - that image of the clean, green country. I think she's actually fighting for every little part of - keep that. So she's trying to keep that and make it real, still realistic and still happening. (Female, Waipukurau)

Remarks such as these suggest that the clean green place myth was perceived as a temporally distant utopian ideal, but one that the Prime Minister and population could fight to achieve. It is one that, in practice, could be realized, and could be extracted from the historical, cultural imagination and fleshed out into a 'concrete' (sic) reality. Such comments identify the potential spatialization (or materialization) of the myth, but as a future project, rather than an event that is already in progress. However, although discourses on the status of clean green New Zealand were temporally polarized and participants admitted that it was a flawed conjecture, when biotechnology entered into this equation, some noteworthy shifts within this far from stable construction occurred. More recently, a counter place myth has been devised by the New Zealand government, that of the country as a centre for biotechnology innovation. When participants were introduced to this alternate idea, which was the main emphasis of focus groups, it raised a number of interesting questions. In the following section, the clean green New Zealand place myth meets the nouveau, embryonic place myth of New Zealand, a centre for biotechnology innovation.

\section{Crystallized out: biotechnology meets clean green New Zealand}

With the recognition that chemically based agricultural inputs created widespread environmental pollution and degraded farmland, biotechnology proposes a 'cleaner', 'greener', and more 'natural' way to manage agricultural resources ... agricultural biotechnology proposes to make an inadequate nature better. (Jones 2000, 10)

As Cloke and Perkins $(1998,191)$ noted, 'newness, freshness and natural nature' are crucial aspects of the 'mental geography' of New Zealand. However, such place images have recently been joined by another: New Zealand as innovative. Consequently, 'the link between establishing meanings about places, and establishing the opportunity to be innovative in approach and action ... is beginning to be forged' $(1998,191)$ in a new attempt to recreate New Zealand. This new image focuses on a New Zealand that is, 'experimenting to find its feet in the world' (The New Zealand Way 1993, 5) and portrays farmers embracing technology through glossy brochure images (The New Zealand Way 1993, 6; Cloke and Perkins 1998, 191). Whilst Cloke and Perkins argued that this focus was used to emphasize New Zealand's new tourist industry innovations, we suggest that it is also an initial attempt to draw clean green New Zealand and (bio) technology into one picture. Such miniaturized pictures adorn the pages of the new Biotechnology Strategy 
pamphlets, depicting 'clean green' fields of bioengineered crops, interspersed with images of young, friendly scientists and test tubes. As Jeanette Fitzsimons, the Green Party coleader, argued, in the new millennium, 'New Zealand diplomats are promoting the country as clean, green and pro-genetic engineering' (Milne 2000). And the manipulation of visual images is a key method to literally draw the two place myths into the same space.

Proponents of the co-dependency of clean green New Zealand and biotechnology (particularly GM technology) play on the environmental benefits of genetic engineering, and the potential consequences for New Zealand if it is not utilized:

If we have a major oil spill and we refuse to use GM bacteria to clean it up, we're not going to look very clean and green. If we can't control possums and lose biodiversity and if plants are developed which can absorb heavy metals and we refuse to use them, we're not going to look clean and green. (Dr William Rolleston, quoted in Hayman 2003, 11)

Similarly, member of the Royal Commission, Richard Randerson stated:

New Zealand is one of the biggest users of 1080 poison for possum control, so GM technologies, such as immuno-contraception, have the capacity to deliver additional environmental benefits. (2003)

During focus groups, a small number of participants supported this argument. They saw biotechnological innovations in the 'environmental stream' as a means to re/construct and actualize the place myth of clean green New Zealand. In this scenario, biotechnology was a tool that could reproduce and remake New Zealand as an imagined Arcadia or Garden of Eden (see Merchant 2003). These narratives regurgitated government marketing: when New Zealand's dominant place myth was under threat from environmental degradation, and hence, national pride at stake, biotechnology could be utilized to reproduce a 'clean green' country. Namely, the two place myths could co-evolve in a mutually beneficial, symbiotic relationship. In these narratives, participants carefully negotiated the risks and benefits of biotechnology versus pesticides and harmful chemicals. As one Waipukurau farmer said: 'We pride ourselves on being a clean and green country . . . then putting something forward that will cut that down, then why not?' He later furthered this assertion, making reference to the importance of new advances in GE to help buttress this image.

As I said before, we pride ourselves on being a clean green country and over the years we've put a lot of crap on our pasture, and that ... So there's still a lot of toxins and that in our grass and our soil, so if we can get rid of that and step back to square one, and find out what's good and what's not ... then chuck whatever on, and the follow-on effects as well - so cleaner, greener grass and that. Have better healthier animals, which have better milk and better meat. (Male, Waipukurau)

In such narratives, biotechnology allows us to turn back time; to begin afresh with a clean slate; to return to the visible, uncontaminated image of ' $100 \%$ PURE New Zealand'. Indeed, this farmer was not alone in his thoughts about the potential environmental benefits of using selective biotechnologies in New Zealand, particularly to boost the place myth of a clean green country.

Male: As long as it's controlled I think it could enhance our clean green image. 
Moderator: Why do you think it would do that?

Male: I just think, I mean, we go on about the 'clean green image', what we have to offer here in terms of environment and things. I just think it would enhance that, our animals, our cows and whatever. We can supply the best of that as well, as we can also supply the best of other things. Yeah, I think it would be good for us, help our image. (Focus Group, Dunedin)

Thus, rather than being perceived as threatening, for some participants, biotechnology was viewed as a useful tool for New Zealanders in the enhancement and perfection of nature. Here, the clean green place myth is portrayed as an end product. With biotechnology, New Zealand becomes a visibly, perfect 'Garden of Eden', that grows without interference from unwanted pests or pesticides. In this discourse, clean and green becomes synonymous with 'picture perfect', rather than being identified with a series of 'natural processes' used to obtain the end result as proposed by organic agriculture. However, although the potential benefits of the two place myths were recognized, they did not always sit comfortably together in the same picture: 'So it's two faces . . . it's an interesting debate, obviously going to produce strong feeling ... at the same time, we're so innovative ... It's two opposite ends of the spectrum' (Female, Christchurch).

Others in New Zealand were not so certain about this uncomfortable juxtaposition and, recently, there was an overriding public concern that the expansion of biotechnology threatened New Zealand's 'clean green' image (IBAC 2000). A recent discussion paper suggested that genetically engineered foods posed a threat to this clean green brand image and reputation for producing healthy food (Small et al. 2002). Just before the moratorium on New Zealand's GM containment was lifted, a survey undertaken by Canterbury-based newspaper, The Press, suggested that 66 per cent of the regional population thought that 'the release of GMOs would have a negative effect on New Zealand's [clean green] image' (Collett 2003, 2). Moreover, research at Lincoln University for the Ministry of the Environment suggested that the release of GMOs would substantially devalue the country's brand image, as international consumers would prove less likely to buy national food products, even if GM-free (Goven 2003).

Our focus groups were characterized by a comparable sounding of alarm bells. When under a perceived threat from GM technology in particular, participants reconstructed the clean green icon and believed that it was useful to make comparisons between present and future states. As a result, New Zealand's place myth was pulled into the present moment. To emphasize this presence, clean green New Zealand was defined by its direct contrast to overpopulated continents such as Europe and Asia, where architects, pressed for space, have been resigned to building skywards. Images of polluted cities continuing their cancerous spread into rural landscapes, churning up the ever-shrinking countryside, were commonplace in these discourses.

Male 1: You see, we think we're losing our clean, green image. You know, you go visit somewhere like Hong Kong, Singapore, they'll always think we're clean and green because...

Male 2: Because they haven't got any!

Male 1: No, the fact they haven't got any space. They've had to build upwards and not outwards because there's no room. (Focus Group, Waipukurau) 
Male: Other countries do think New Zealand has this perfect clean green image but its not as perfect as everyone makes out.

Female: By comparison perhaps we are clean and green? (Focus Group, Auckland)

Although comparatively speaking, participants argued that New Zealand was clean and green, many participants felt that the country could not maintain this image and submit to biotechnological progress. For many, the place myths of biotechnology innovation and a clean green country were contradictory and could not co-evolve. This was apparent in statements such as: 'GE, don't want that, want to stay clean and green' (Female, Christchurch). Contrary to the government's vision, genetic engineering was perceived as a destabilizing threat to the place myth of clean green New Zealand.

This clash of place myths was particularly evident when participants discussed the emotive topic of introducing synthetic toad genes into potatoes: 'If we want natural clean green, it doesn't include potatoes that have been syringed with toad genes in the lab and multiplied' (Female, Dunedin).

Female: Some of these developments have side effects. We could destroy the very thing that we say $\mathrm{NZ}$ is great.

Male: The potato. That has the potential to really damage our green economy. (Focus Group, Auckland)

It was noticeable that the 'toad potato' as some participants called it, featured highly in critiques of 'biotechnology' as they related to this national icon, suggesting that to some, GE was biotechnology. ${ }^{7}$ Thus, for these opponents of biotechnology, clean green New Zealand was mobilized, and drawn into the present moment as a means of defence against what was perceived to be an impending threat to this emotive place myth. In particular, the use of genetic engineering was argued to be a direct threat to the maintenance of the place image created by organic farming; a place image that feeds the myth of clean green New Zealand.

Overall, attitudes to the co-evolution of the clean green place myth and New Zealand as biotechnology innovator were somewhat ambivalent, verging on polarized. They were clearly dependent upon the way this icon was understood and valued by participants. For many proponents of biotechnology, nature was there to be perfected at the surface level with the potential (re)emergence of 'squeaky' clean New Zealand, with its relative environmental imperfections mobilized as an impetus to utilize these measures. Conversely, for biotechnology's opponents, nature was revered as a wilderness dominated by images of untainted mountains, lakes and bush. In particular, a place image of pure New Zealand ${ }^{8}$ was utilized to support such assertions, and a comparative stance to less pure regions adopted to bring the place myth of clean green New Zealand directly into the present.

\section{Conclusion}

The marketing of New Zealand to the global community has relied upon the place myth of clean green New Zealand for a number of years. Based upon a complex genealogy that involves nature as a key actor in the making of the Kiwi identity, this clean green image manifested persuasively in focus group discussions on the future of New Zealand and the 
use of biotechnology in the country. Participant's responses to clean green New Zealand were complex and fragmented, and almost always tinged with emotion whether they saw it as a marketing myth or an icon symbolic of national identity.

Spatially, this national icon has been channelled into tourist corridors, segregating pristine nature from the hidden scars of logging operations, polluted waterways and apparently clean and green forests managed through the use of pesticides. Furthermore, in the public imagination, clean green New Zealand was not so much a part of everyday life but a temporally distant Utopian space. In response to the encroachment of environmental degradation, it was perceived as either traditional nature, lurking in the memories of childhood and glossy brochures or a projection of how the future New Zealand should look.

More recently, the clean green New Zealand place myth has been juxtaposed to that of New Zealand as a core of biotechnology innovation. This political juxtaposition evoked a variety of reactions from focus group participants. When the nation's clean and green icon was perceived to be threatened by GE, its relative, comparative status was mobilized, a manoeuvre that drew this utopian ideal into the present tense. Thus, in contrast to Asia and Europe, where population pressure forced the cancerous march of urban sprawl into areas of aesthetic beauty, New Zealand still looked pure and unsullied. Against this backdrop, specific biotechnologies such as genetic engineering/modification were disapproved of and identified as detrimental to the maintenance of a clean green country. The two place myths were not compatible, for genetic engineering was riddled with unforeseen consequences that threatened the 'natural' environment and New Zealand's international reputation in agriculture and tourism.

Whilst a significant number of participants were adamant in their concern that genetic engineering would ruin this national image, others saw the potential for the development of an environmentally sustainable New Zealand, in league with new biotechnological innovations that would allow the country to compete in an international marketplace. A small minority of participants saw that biotechnologies such as using a bacteria-filled bolus to cut down on agricultural greenhouse gas production, genetically modified viruses as a means of environmental remediation, and insect-resistant crops to cut down on pesticide use, if 'safe', could re-construct clean green New Zealand for the benefit of all.

Theoretically, this research supports the conflicts and discrepancies inherent in the process of social spatialization, and the usurpation of one dominant place myth by another. Place myths are extremely complex, dynamic and, we argue, can be fragmented in time and space. This latter characteristic allows them to be mobilized into different contexts to serve a multitude of political and counter-political purposes. In this case, for the New Zealand government, both the clean green and biotechnology innovation place myth fulfil economic and hence inherently political prerogatives. However, these purposes were a different kind to those emphasized by focus group participants, who pointed out the fallacy and incompatibility of these two place myths. It seems that the border zone between the two is fraught with a shifting tension, and for the government, smoothing this tension is a matter of fine-tuning the meaning of the two place myths so that the two can be overlaid. In this particular case, we speculate that the New Zealand government is currently marketing this compatibility through three major means.

Firstly, images that depict the visual perfection of nature through biotechnology. Genetic engineering has been fleshed out as 'perfect potatoes', 'clean green' fields, long-life foods 
and medical formulas to save New Zealanders' lives. However, the majority of focus group participants had a different conception of 'clean green' nature, a cynical distrust of 'perfect potatoes' and an astute ability to see beneath this marketing hype. Secondly, if the government can rid genetic engineering of its 'unproven' safety concerns, then it can be marketed as a 'clean' technology, in comparison with the heavy industries that pollute Europe, North America and Asia. As members of the Asian focus group noted, biotechnology is a 'value added' product, with high export value. Thirdly, in order to enhance this marketing of biotechnology, emphasis is being drawn away from controversial GE products and towards the promotion of New Zealand-based businesses, rather than embracing multinationals such as Monsanto. ${ }^{9}$ However, during focus groups, whilst such ploys were usually ridiculed by participants, others from lower socio-economic groups were only vaguely aware of either place myth, or found them relevant to their everyday lives.

In contrast, arguments against this co-evolution of the two place myths include references to threats to the safety and the unpredictability of bioengineered products that could irreversibly jeopardize clean green New Zealand, impacting on tourism, organic agricultural exports, but more importantly on the lifeworld that Kiwis call 'home'. This view of clean green New Zealand as 'home' rather than a commodity takes it beyond the category of a mere marketing myth and into community ideals. It goes beyond economic value. In metaphorical terms, it seems that whilst New Zealanders may have swallowed and appropriated the marketing myth of clean and green, genetic engineering does not have the same pleasant taste and is likely to cause indigestion when eaten alongside the former.

As a result, it appears that the two place myths currently sit uncomfortably beside one another; the glossy brochure images of co-evolution have not entirely filtered down into the public imagination. Rather, the increasing transparency of the practices of genetic engineering undermines the representation of a 'perfect nature' that can be created using such tools. As a result, we have to conclude that there is a clash of ideologies between proponents and opponents of the compatibility of the two place myths. Is the way to flesh out the place myth of clean green New Zealand through the perfection of the product using 'artificial' practices, or through practices such as conservation, organic agriculture and the official (re)creation of tracts of wilderness? New Zealand's clean green image currently rests uneasily at a bifurcation point, awaiting an uncertain destiny.

I think we're all agreed on the clean, green side of it. How green we are is up to debate. I think where our future lies is working to our advantage, which is in the natural environment we do have. We don't need to compete in every technological and scientific advance but work to the areas where can actually gain the best advantage. (Male, Auckland) 


\section{Notes}

1 In comparison, space myths, usually applied to nations, ‘ . . form a mythology or formation of positions which polarizes and dichotomizes different places and spaces' (Shields 1991, 62). Place and space myths are interrelated, and their relative identities defined by this often complex relationship to one another. And it is a relationship characterized both by a cultural imaginary and the embodied, grounded practices of everyday life.

2 ' $100 \%$ PURE New Zealand' was a government-inspired branding of the country for the purposes of marketing it as a tourist destination. The branding was accompanied by images of crystal clear lakes, and 'clean green' countryside, and the use of capital letters, emphasized the word 'pure' as a signifier for New Zealand.

31080 , or sodium monofluoroacetate, is a tasteless, odourless, naturally occurring, but somewhat controversial poison used for the control of possums and other non-native species that were introduced by settlers to New Zealand in the 1800s. These species found a niche and multiplied their numbers to proportions that were considered to be damaging to the local ecosystem. Possums were introduced from Australia, where they are understood by New Zealanders to be an endangered and hence protected species. To the contrary, in New Zealand, such 'pests' cause visible damage to native plants and trees. Unfortunately, undiscriminating applications of 1080 have led to the death of native birds such as weka, tomtits and riflemen.

4 Focus groups allow the flexibility to explore new ground, and to spark creative ideas (Morgan 1988). In practice, this exploratory attribute provided the key to unlocking pent-up emotions and critiques that were not viewed as part of 'everyday talk' by our participants. Moreover, it was the interactions between participants that led to insights not revealed through other methods such as interviewing, where it is the researcher who solely responds to their research subject (Morgan 1988; Cameron 2000). Such interaction gives participants the opportunity to reflect upon perspectives other than their own and then reconsider their own ideas on the topic in relationship to those of the group (Cameron 2000; Pini 2002). The interactive nature of focus groups can also lead to the spontaneous emergence of often unpredictable responses. Albeit a researchconstructed situation, such spontaneity approximates participants' everyday decisionmaking process, allowing them to seek clarification if needed (Morgan 1988). Namely, focus groups can act as a microcosm for everyday life. Furthermore, the spontaneity and interaction characteristic of focus groups also allows researchers to clarify statements, ask follow-up questions, probe participants on interesting issues that arise, and explore unanticipated responses (Stewart and Shamdasani 1990; Krueger 1994). Indeed, one of the main goals of focus groups is to approach the participant's understandings of the research topic; not only what they think but, 'why participants think as they do' (Stewart and Shamdasani 1990, 12). The result is a 'very rich body of data expressed in the respondent's own words and context' (Stewart and Shamdasani 1990, 12) that allows researchers a more complex understanding of social reality (Knap and Propst 2001, $62)$.

5 For more details on these themes, refer to Coyle et al. (2003).

6 Coyle et al. (2003, 62-5).

7 When asked what they associated with the term biotechnology, the majority of participants immediately referred to genetic engineering or genetic modification. For some, the term 'biotechnology' was 'GE', an observation that has been backed up by the results of a follow-up, large-scale national survey (Cook et al. 2004).

8 See Coyle et al. $(2003,64-5)$. 
9 This information emerged during a meeting with stakeholders, who were concerned that the New Zealand public should see the potential for small, locally managed businesses to enter into the biotechnology market.

\section{References}

Beck U 1992 Risk society Routledge, London

Bell C 1996 Inventing New Zealand: everyday myths of Pakeha identity Penguin Books, Auckland

Bell C 2002 Sustaining the clean green myth Public lecture at the University of Auckland 30 July

Bonaface L 2003 Gene genie The Dominion Post 13 September edition 21

Cameron J 2000 Focusing on the group in Hay I ed Qualitative research methods in human geography Oxford University Press, Melbourne

Cloke P and Perkins H C 1998 'Cracking the canyon with the awesome foursome': representations of adventure tourism in New Zealand Environment and Planning D: Society and Space $16185-218$

Collett G 2003 Four fifths want G M ban The Press 11 October edition 22

Cook A J, Fairweather J R, Satterfield T and Hunt L M 2004 New Zealand public acceptance of biotechnology AERU report no 269 Lincoln University, New Zealand

Coyle F J, Maslin C, Fairweather J R and Hunt L M 2003 Public understandings of biotechnology in New Zealand: nature, clean green image and spirituality AERU report no 265 Lincoln University, New Zealand

Dew K 1999 National identity and controversy: New Zealand's clean green image and pentachlorophenol Health and Place 5 45- 57

Fleming G 2002 Clean, green image under threat - report The Dominion Post 5 August edition 22

Gendall P J, Healey B, Robbie P, Gendall K, Patchett S and Bright N 2001 New Zealanders and the environment Massey University, New Zealand

Goven J 2003 Joanna Goven: GM release a gamble not worth the candle The New Zealand Herald 24 October

Hayman K 2003 GM crops 'good for New Zealand' The Press 13 October edition 211

Jones K 2000 Constructing rBST in Canada: biotechnology, instability and the management of nature Canadian Journal of Sociology 25 311- 41

Knap N E and Propst D B 2001 Focus group interviews as an alternative to traditional survey methods for recreation needs assessments Journal of Park and Recreation Administration 19 62- 82

Krueger R 1994 Focus groups: a practical guide for applied research 2nd edn Sage, Thousand Oaks CA 
Merchant C 2003 Reinventing Eden: the fate of nature in western culture Routledge, London

Milne J 2000 Clean, green, pro-GE image angers MP The Dominion 20 June edition 16

Ministry for the Environment 2001 Our clean green image: what's it worth? MAF publication August

Morgan D 1988 Focus groups as qualitative research Qualitative research methods series 16 Sage University Paper, Newbury Park

Morgan J 2002 A snapshot of how it should be The Dominion 25 May edition 23

Murdoch H 2001 Clean and green 1080? The Press 19 June edition 221

Napp B 2002 If it's good to kill possums, why do we hate 1080? The Dominion Post 22 August edition 25

Parker D 2000 Saving NZ's clean green image The Daily News 26 February edition 18

Pini B 2002 Focus groups, feminist research and farm women: opportunities for empowerment in rural social research Journal of Rural Studies 18 339- 51

Prestwood S 2001 Downstream from the dairy boom The Dominion 18 August edition 25

Randerson R 2003 Richard Randerson: many angles to consider in assessing G M debate The New Zealand Herald 28 October

Sanderson K, Saunders C, Nana G, Stroombergen A, Campbell H, Fairweather J and Heinemann A 2003 Economic risks and opportunities from the release of genetically modified organisms in New Zealand Ministry of the Environment, Wellington

Shields R 1991 Places on the margin: alternative geographies of modernity Routledge, London

Shultis J D 1989 Images and use of New Zealand's protected areas by domestic and international visitors GeoJournal 19 329- 35

Small B H, Wilson J A and Parminter T G 2002 Clean, green and healthy? Genetically engineered food: a perceived threat to New Zealand's brand image Paper presented at the Eighth Annual Conference of the New Zealand Agricultural and Resource Economics Society Blenheim, July 2002 AERU discussion paper no 149 96- 100

Stewart D W and Shamdasani P N 1990 Focus groups: theory and practice Applied social research methods series 20 Sage, Newbury Park

The New Zealand Way 1993 Brand New Zealand New Zealand Way Ltd, PO Box 5241, Wellesley Street, Auckland 